\title{
Filtrasi Ampas Jahe Menggunakan Filter Press
}

\author{
Ade Lina Yulifianti*, Bella Eristi R., Mawar Puspita N. Dwi Handayani \\ Departemen Teknologi Industri, Sekolah Vokasi, Universitas Diponegoro \\ Jl. Prof. Soedarto, Tembalang, Kota Semarang, Jawa Tengah 50275, Indonesia \\ Email: adelinafianti@gmail.com
}

\begin{abstract}
Abstrak
Ampas jahe hasil buangan proses industri jamu masih mengandung sari jahe. Pengolahan ulang dengan pelarutan dan penyaringan dengan plate and frame filter press dapat dilakukan untuk mengisolasinya. Penggunaan variabel konsentrasi umpan 0,2 kg/liter, 0,4 kg/liter, dan 0,6 kg/liter. Menggunakan tekanan

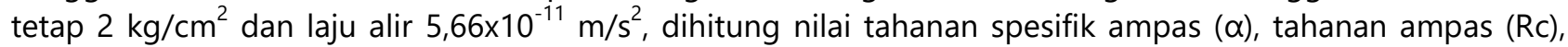
tahanan medium filter $(\mathrm{Rm})$ untuk mengetahui efesiensi kinerja alat filter press. Proses filtrasi dilakukan secara batch. Hasil perhitungan menunjukkan nilai $\alpha, \mathrm{Rc}$, dan Rm tertinggi pada konsentrasi $0,6 \mathrm{~kg} / \mathrm{L}$ yaitu $\alpha$ $\left(4,98 \times 10^{6} \mathrm{~m} / \mathrm{kg}\right), \operatorname{Rc}\left(1,35 \times 10^{8} \mathrm{~m}^{-1}\right), \operatorname{Rm}\left(3,79 \times 10^{11} \mathrm{~m}^{-1}\right)$. Efektivitas produk yang dihasilkan diketahui melalui pengukuran konsentrasi sari jahe pada hasil filtrat. Pengujian konsentrasi menggunakan centrifuge dan analisa Total Suspended Solid (TSS). Hasil analisa centrifuge menyatakan bahwa semakin besar konsentrasi umpan, maka semakin besar pula konsentrasi produk. Konsentrasi sari jahe tertinggi yang didapat 6,67\%, terdapat pada variable konsentrasi umpan $0,6 \mathrm{~kg} /$ liter. Begitu pula dengan uji TSS, konsentrasi umpan 0,6 kg/liter menghasilkan TSS terbesar yaitu $277 \mathrm{mg} / \mathrm{l}$.
\end{abstract}

Kata Kunci : Ampas jahe, filtrasi, konsentrasi, filter press

\section{Abstract}

\section{Ginger Pulp Filtration Using Filter Press}

Ginger pulp from the process of industrial herbs still contains ginger juice. Reprocessing ginger pulp with dissolving and filtering with plate and frame filter press be done to isolate it. Use feed variable concentration 0.2 $\mathrm{kg} /$ liter, $0.4 \mathrm{~kg} /$ liter, and $0.6 \mathrm{~kg} /$ liter. Fixed pressure used is $2 \mathrm{~kg} / \mathrm{cm}^{2}$ and flow rate use $5.66 \times 10^{-11} \mathrm{~m} / \mathrm{s}^{2}$, will calculate the specific prisoner value of the pulp $(\alpha)$, Prisoner of Pulp $(R c)$, Prisoner of medium filter $(R m)$ to know the efficiency of the performance of filter press. The filtration process done in batches. The results of the calculation show the highest value of $\alpha, R c$, and $R m$ at concentrations $0.6 \mathrm{~kg} /$ litre are $\alpha\left(4.98 \times 10^{6} \mathrm{~m} / \mathrm{kg}\right), R c$ $\left(1.35 \times 10^{8} \mathrm{M}^{-1}\right), R m\left(3.79 \times 10^{11} \mathrm{M}^{-1}\right)$. Effectiveness of the resulting products was known through measurements of ginger juice concentrations infiltrate results. Concentration testing using a centrifuge and Total Suspended Solid (TSS) analysis. Result of centrifuge analysis states that the greater the concentration of feed, that the greater the concentration of the product. The highest concentrations of ginger juice gained $6.67 \%$, there is a variable concentration feed $0.6 \mathrm{~kg} /$ litre. Similarly, the test of TSS, the concentration feed $0.6 \mathrm{~kg} /$ litre resulted in the largest TSS $277 \mathrm{mg} / \mathrm{l}$.

Keywords : Ginger pulp, filtration, concentration, filter press

\section{PENDAHULUAN}

Ampas jahe yang dihasilkan dari proses pengepresaan, biasanya langsung dibuang atau dijadikan pakan ternak. Mengingat kandungan sari jahe yang masih tertinggal di dalam ampas jahe masih memiliki nilai ekonomis, maka dilakukan pengolahan kembali. Pengolahan kembali dapat 
meningkatkan efesiensi produk dan mengurangi limbah buang. Proses pemoptimalan pengambilan sari jahe dari ampas jahe dapat dilakukan dengan pelarutan dan filtrasi kembali (Handayani dan Ikhsan, 2012).

Filtrasi (penyaringan) adalah proses pemisahan antara padatan/koloid dari cairan (Rachma dan Suparno, 2016). Filtrasi dapat juga diartikan sebagai proses pemisahan liquid-liquid dengan cara melewatkan liquid melalui media berpori atau bahan-bahan berpori untuk menyisihkan atau menghilangkan sebanyakbanyaknya butiran-butiran halus zat padat tersuspensi dari liquda (Pangestu, 2016). Salah satu alat filter yang sering digunakan adalah filter press. Menurut Sutherland 2008, filter press merupakan salah satu jenis filter tertua. Filter press selama seabad terakhir menjadi filter tekanan proses yang paling penting, dan tetap penting hingga hari ini, meskipun terdapat jenis filter yang kompetitif. Filter ini telah menjaga peran utama dalam perkembangan media filter yang memungkinkannya untuk mengimbangi permintaan pasar untuk efisiensi penyaringan yang ditingkatkan, efisiensi energi yang lebih baik, tingkat kejernihan yang lebih tinggi dalam filtrat dan beberapa ukuran otomatisasi. Hampir setiap jenis media filter, tersedia dalam bentuk lembaran dan dengan kemampuan untuk menolak perbedaan tekanan yang terlibat dalam filter press. Banyak industri yang lebih memilih untuk menggunakan sistem filter bertekanan (filter press) untuk proses penyaringan dan pemurnian bahan. Alat ini akan bekerja berdasarkan driving force, yaitu perbedaan tekan. Alat ini dilengkapi dengan kain penyaring yang disebut filter cloth, yang terletak pada tiap sisi platenya untuk memisahkan padatan cairan dengan media berpori yang meneruskan cairannya dan menahan padatannya (Geankoplis, 1983).

Penilaian kinerja alat dan hasil produk dapat digunakan sebagai tolak ukur sebagai efektivitas kinerja alat. Efektivitas kinerja alat dapat ditinjau berdasarkan nilai Tahanan Medium Filter (Rm), Tahanan Ampas (Rc), Tahanan Spesifik Ampas ( $\alpha$ ), dan laju filtrasi. Sedangakan efektivitas produk dapat ditinjau dari besar kecilnya konsentrasi produk yang dihasilkan. Parameter tersebut diuji dan dibandingkan dengan hasil variasi konsentrasi feed pada saat proses filtrasi.
Penelitian ini bertujuan mengetahui konsentrasi feed terbaik yang menghasilkan efektivitas produk tertinggi dan efesiensi kinerja tertinggi plate and frame filter press dalam proses.

\section{METODOLOGI}

Penelitian ini dilakukan di Laboratorium OTK Teknik Kimia Universitas Diponegoro dengan sampel ampas jahe yang dihasilkan dari home Industri UD Tiga Dara di daerah Ungaran Jawa Tengah. Pengujian ditinjau dari efektivitas kinerja alat meliputi nilai Tahanan Medium Filter (Rm), Tahanan Ampas (Rc), Tahanan Spesifik Ampas ( $\alpha$ ) menggunakan metode perhitungan excel sebagai penentu nilai slope dan intersept. Sedangkan pengujian efesiensi produk diketahui berdasarkan konsentrasi produk sari jahe melalui Uji Total Suspended Solid (TSS) dan Centrifuge sebagai pendekatan nilai besar konsentrasi produk sari jahe. Rancangan pengujian menggunakan alat Plate and Frame Filter Press dengan kondisi

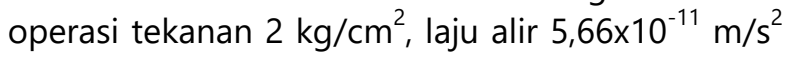
dan variable bebas yang digunakan adalah konsentrasi umpan larutan jahe 0,2 kg/liter , 0,4 $\mathrm{kg} / \mathrm{liter}$ dan 0,6 kg/liter.

Tahap awal yaitu penyiapan alat dan preparasi sampel. Tahap berikutnya melakukan proses filtrasi tiap variable dan mencatat $\mathrm{v} / \mathrm{t}$ filtrat yang keluar. Nilai tahanan medium filter dan nilai tahanan ampas dapat dihitung berdasar nilai slope dan intersept dari grafik yang dihasilkan. Nilai konsentrasi produk diukur melalui pendekatan nilai hasil uji TSS dan centrifuge.

\section{HASIL DAN PEMBAHASAN}

Penelitian pengambilan sari jahe dengan metode filtrasi, menggunakan alat filter press plate and frame. Pengoptimalah proses dilakukan dengan menggunakan konsentrasi feed yang berbeda yaitu $2 \mathrm{~kg}$ ampas jahe dalam 10 liter air, 4 $\mathrm{kg}$ ampas jahe dalam 10 liter air dan $6 \mathrm{~kg}$ ampas jahe dalam 10 liter air. Variable kendali lainnya yaitu menggunakan tekanan $2 \mathrm{~kg} / \mathrm{cm}^{2}$, laju alir umpan $5,66 \times 10^{-11} \mathrm{~m} / \mathrm{s}^{2}$, suhu terukur $34^{\circ} \mathrm{C}$.

Mekanisme kerja alat filter press ini adalah umpan larutan ampas jahe masuk dari tangki feed lalu masuk ke alat melaui pipa. Pada alat filter press terdapat plate dan frame serta dua filter cloth untuk setiap frame. Ampas jahe yang masuk 
disaring dan cake akan menempel pada filter cloth. Filtrat dari proses ini akan mengalir melalui saluran lalu masuk ke tangki penampungan. Data filtrasi $t / v$, densitas dan viskositas digunakan untuk menghitung nilai tahanan spesifik ampas $(\alpha)$, tahanan ampas $(\mathrm{Rc})$, tahanan medium filter $(\mathrm{Rm})$ dan laju filtrasi (dv/t). Analisa konsentrasi filtrat juga dilakukan dengan cara sentrifugasi dan analisa TSS untuk mengetahui variable yang menghasilkan sari jahe paling optimum.

\section{Mencari Nilai Slope dan Intersep dengan Kurva $t / \mathbf{V}$ vs V}

Nilai $t / V$ vs $V$ digunakan untuk mencari slope dan intersep dalam persamaan $y=a x+b$. Slope dimasukkan sebagai nilai Kp dan Intersep nilai $B$ dalam rumus penentuan tahanan spesifik ampas $(\alpha)$, tahanan ampas $(\mathrm{Rc})$, tahanan medium filter (Rm) dan laju filtrasi (dv/t). Data $t / V$ diperoleh saat proses filtrasi. Filtrat yang keluar dari valve keluaran proses diukur waktu setiap volume filtrat kelipatan $50 \mathrm{ml}$ di awali dari $100 \mathrm{ml}$ dan diakhiri $500 \mathrm{ml}$. Nilai $\mathrm{t} / \mathrm{V}$ diplotkan berbanding dengan volume (dalam $\mathrm{m}^{3}$ ) sehingga didapat persamaan garis pada konsentrasi 0,2 $\mathrm{kg} /$ liter adalah $\mathrm{y}=1793,9 \mathrm{x}+70571$, pada konsentrasi $0,4 \mathrm{~kg} /$ liter adalah $\mathrm{y}=3876,4 \mathrm{x}+119155$ dan pada konsentrasi $0,6 \mathrm{~kg} / \mathrm{L}$ adalah $7311,77 \mathrm{x}+$ 205284 (Gambar 1).
Terlihat pada Gambar 1, bahwa setiap variable konsentrasi yang berbeda, garis lurus yang didapatkan berbeda. Konsentrasi 0,2 kg/liter memiliki nilai $\mathrm{t} / \mathrm{V}$ paling kecil disusul konsentrasi 0,4 dan $0,6 \mathrm{~kg} / \mathrm{L}$. Hal tersebut menyatakan bahwa semakin tinggi konsentrasi umpan, makan hasil filtrat yang keluar akan membutuhkan waktu semakin lama.

\section{Hubungan Antara Konsentrasi dengan Tahanan Spesifik Ampas $(\alpha)$ dan Tahanan Ampas (Rc)}

Berdasarkan data dari persamaan garis $t / \mathrm{V}$ vs $V$, maka nilai tahanan spesifik ampas $(\alpha)$ dan tahanan ampas (Rc) dapat ditentukan. Terlihat grafik pada Gambar 2, tahanan spesifik ampas, pada konsentrasi $0,2 \mathrm{~kg} / \mathrm{l}$ nilai a sebesar $4,38 \times$ $10^{8}$, pada konsentrasi $0,4 \mathrm{~kg} / \mathrm{l}$ sebesar 4,44, $\times 10^{8}$ dan pada konsentrasi $0,6 \mathrm{~kg} / \mathrm{l}$ sebesar 4,95 $\times 10^{8}$. Sedangkan pada grafik Gambar 3 tahanan ampas $(\mathrm{Rc})$, pada konsentrasi $0,2 \mathrm{~kg} / \mathrm{l}$ nilai Rc sebesar $3,96 \times 10^{7}$, pada konsentrasi $0,4 \mathrm{~kg} / \mathrm{l}$ sebesar 8,05 , x $10^{7}$ dan pada konsentrasi $0,6 \mathrm{~kg} / \mathrm{l}$ sebesar $1,35 \times$ $10^{8}$. Tahanan spesifik ampas $(\alpha)$ merupakan hambatan yang dimiliki oleh suatu ampas tertentu terhadap slurry. Konstanta $\alpha$ berfungsi umtuk mempermudah perhitungan dalam memperkirakan berapa jumlah filtrat yang dihasilkan dalam waktu tertentu dan untuk

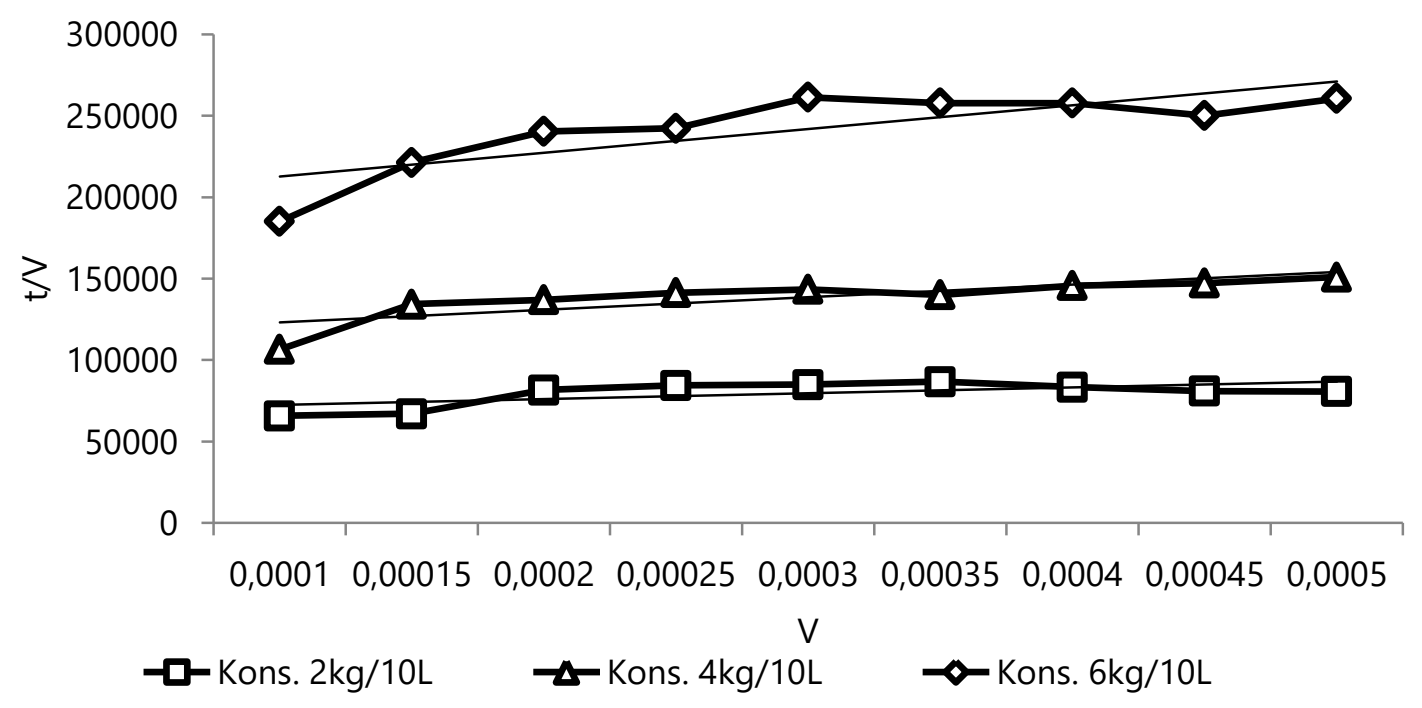

Gambar 1. Grafik Hubungan t/V vs V 


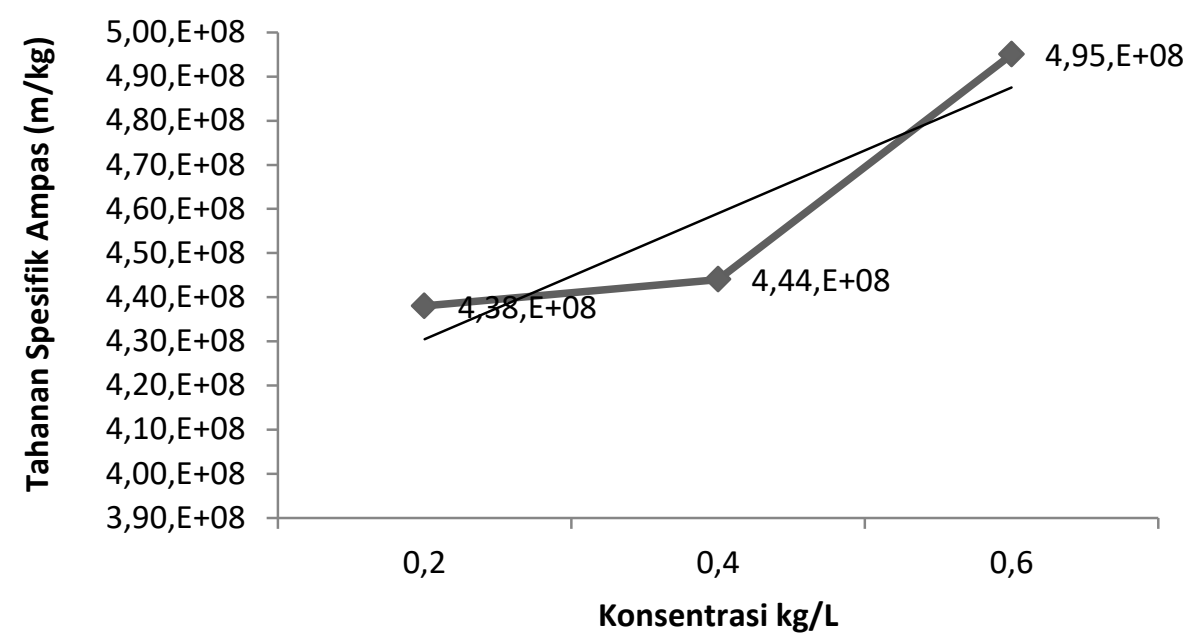

Gambar 2. Grafik Hubungan Konsentrasi dengan Tahanan Spesifik Ampas ( $\alpha$ )

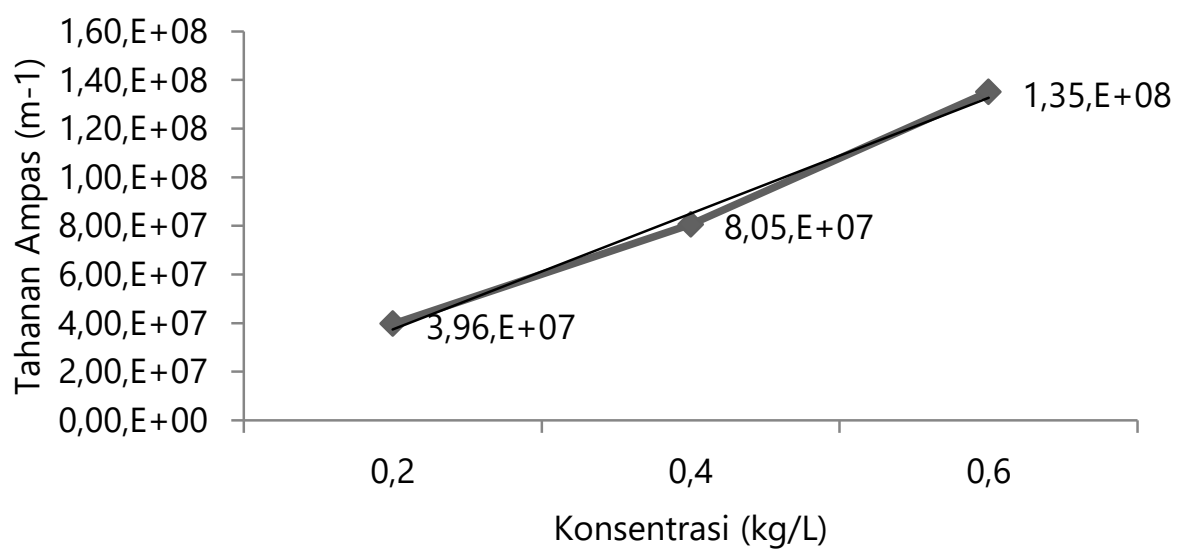

Gambar 3. Grafik Hubungan Konsentrasi dengan Tahanan Ampas (Rc)

menghitung waktu yang diperlukan untuk mendapat sejumlah volume filtrat tertentu.

Nilai tahanan spesifik ampas dan tahanan ampas mengalami kenaikan seiring naiknya konsentrasi umpan meskipun kenaikan tidak signifikan. Hal ini dikarenakan viskositas umpan yang semakin tinggi sehingga akan banyak ampas yang tertahan pada filter cloth sehingga filtrat yang keluar akan membutuhkan waktu yang lebih lama.

\section{Hubungan Antara Konsentrasi dengan Tahanan Medim Filter (Rm)}

Selain nilai tahanan spesifik ampas dan tahanan ampas, nilai tahanan medium filter juga dapat dihitung dari hasil data sebelumnya. Terlihat dari kurva Gambar 4, semakin besar konsentrasi umpan maka nilai tahanan medium filter semakin meningkat. Pada konsentrasi umpan $0,2 \mathrm{~kg} / \mathrm{l}$ nilai $\mathrm{Rm}$ sebesar $1,79 \times 10^{11}$, konsentrasi $0,4 \mathrm{~kg} / \mathrm{l}$ sebesar 2,39 × $10^{11}$ dan konsentrasi $0,6 \mathrm{~kg} / \mathrm{l}$ sebesar $3,79 \times 10^{11}$. Nilai tahanan medium filter akan semakin meningkat seiring meningkatnya konsentrasi umpan. Konsentrasi umpan yang meningkat membuat tahanan spesifik ampas meningkat, dan ketika tahanan spesifik ampas tinggi makan tahanan medium filter juga tinggi karena banyaknya ampas yang tertahan pada filter.

Secara teori, tahanan medium filter dan tahanan cake berbanding lurus dengan konsentrasi slurry (Sahruromdon dan Septiriana, 
2017). Namun pada penelitian yang dilakukan oleh Sahruromdon dan Septiriana (2017), ada penambahan perbedaan variabel jumlah plate sehingga hasil yang didapatkan kurang sesuai, dimana konsentrasi slurry yang digunakan adalah $1 \%$; $1,5 \%$; dan $2 \%$. Kesimpulan hasil tahanan cake terendah pada konsentrasi 1,5\%. Penelitian lebih lanjut dengan pengukuran konsentrasi filtrat dapat dilakukan untuk menjelaskan perbedaan hasil dari teori yang sudah dipaparkan.

\section{Hubungan Antara Konsentrasi Umpan dan Konsentrasi Sari Jahe yang Dihasilkan}

Konsentrasi ampas jahe yang diumpankan, selain mempengaruhi konstanta-konstanta filtrasi yang lebih mengarah keperancangan alat, ternyata juga sangat berpengaruh pada hasil produk (Gambar 5).
Sari jahe sebagai tujuan utama filtrasi, perlu diukur konsentrasinya untuk menentukan variable konsentrasi umpan terbaik. Pengukuran konsentrasi dapat dilakukan dengan metodemetode sederhana salah satunya yang kami gunakanan untuk analisa adalah dengan cara sentrifugasi dan analisa TSS dengan gravimetri.

Filtrat dari berbagai variabel konsentrasi yang keluar dari valve keluaran filtasi ditampung dan disentrifug selama kurang lebih 10 menit maka akan terbentuk 2 lapisan antara sari jahe dan air. Besar kecilnya konsentrasi sari jahe dapat diukur tinggi rendahnya lapisan pertama berbanding dengan tinggi keseluruhan cairan. Dilihat dari kurva Gambar 5, didapatkan dari variable konsentrasi umpan 0,2 kg/l dihasilkan konsentrasi sari jahe sebesar $5 \%$. Untuk konsentrasi umpan 0,4 kg/l dan 0,6 kg/L masing-masing yaitu 6,11\%

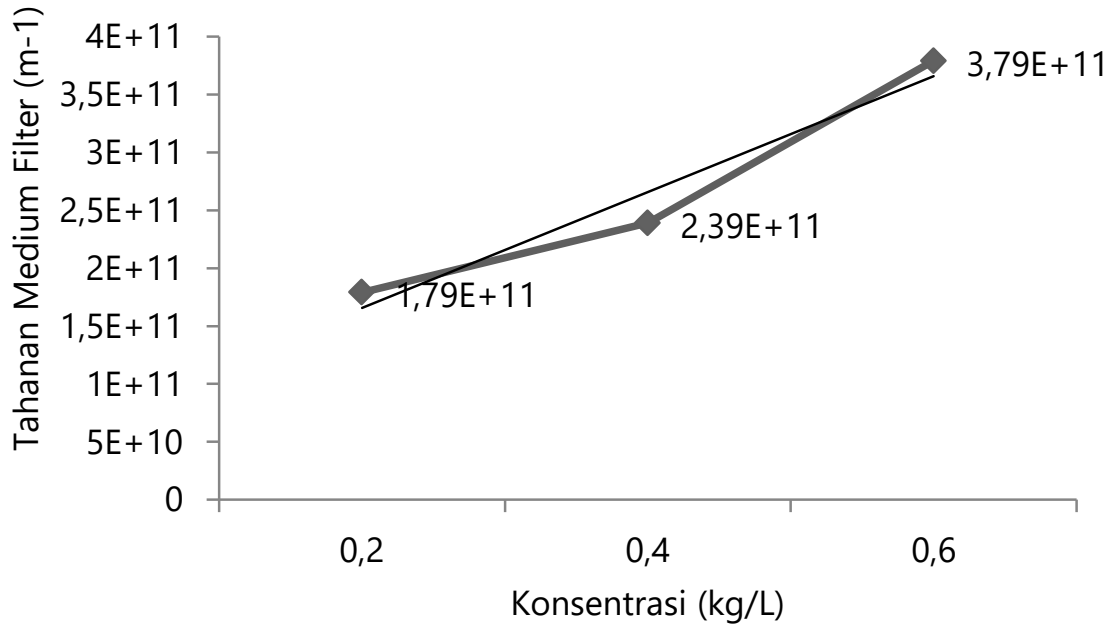

Gambar 4. Kurva Hubungan Tahanan Filter vs Konsentrasi

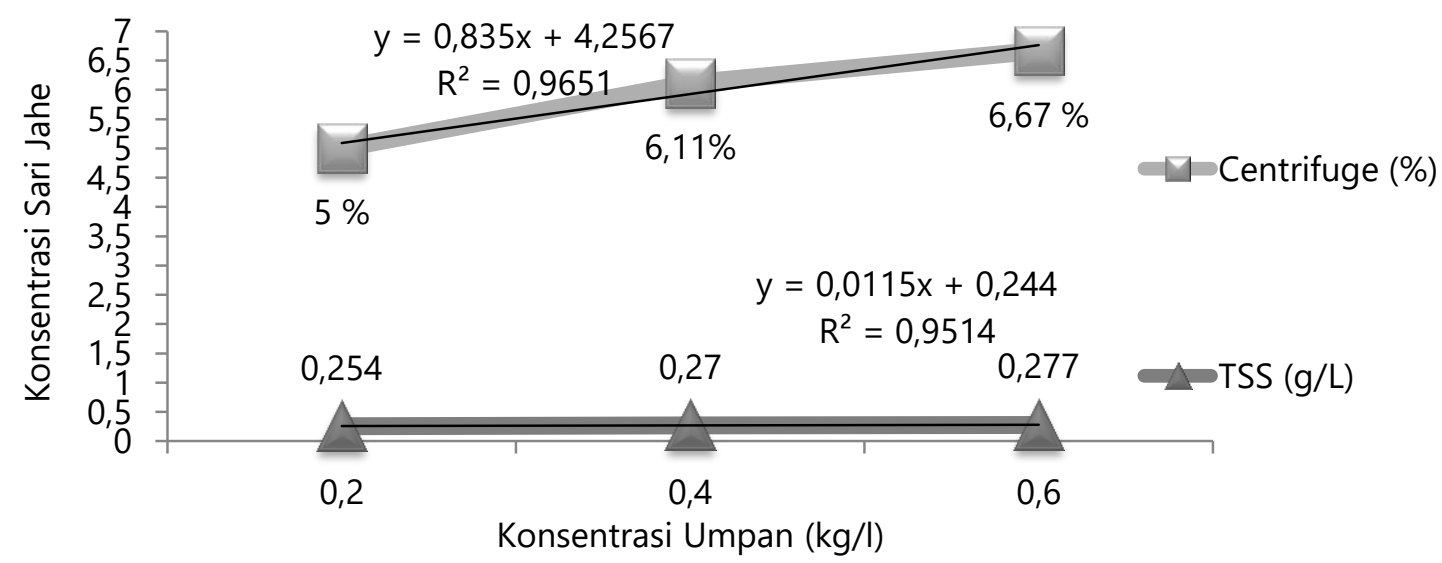

Gambar 5. Kurva Hubungan Konsentrasi Umpan dan Konsentrasi Sari Jahe 
dan 6,67 \%. Konsentrasi sari jahe mengalami peningkatan seiring meningkatnya konsentrasi umpan ampas jahe. Namun peningkatan konsentrasi sari jahe tidak begitu signifikan. Begitu pula dalam uji TSS. Padatan yang tertahan pada kertas saring dianggap sebagai sari jahe sedangakan air akan lolos penyaringan. Pada variable konsentrasi $0,2 \mathrm{~kg} / \mathrm{l}$ nilai total suspended solid sebesar 0,254 g/l atau $254 \mathrm{mg} / \mathrm{l}$. Pada konsentrasi 0,4 kg/l sebesar $270 \mathrm{mg} / \mathrm{l}$ dan konsentrasi 0,6 kg/l sebesar $277 \mathrm{~kg} / \mathrm{l}$. Hal ini sudah sesuai teori dimana konsentrasi umpan yang semakin tinggi, makan konsentrasi ampas jahe yang dihasilkan akan semakin besar.

\section{KESIMPULAN}

Berdasarkan hasil penelitian yang telah kami lakukan dengan melakukan 3 variable uji beda konsentrasi umpan ampas jahe 0,2 kg/L, 0,4 $\mathrm{kg} / \mathrm{L}$ dan 0,6 kg/L, dapat diketahui bahwa Nilai tahanan spesifik ampas $(\alpha)$, Nilai tahanan ampas $(\mathrm{Rc})$, dan Nilai tahanan medium filter (Rm) terendah, masing-masing yaitu $4,38 \times 10^{6} ; 3,3 \times$ $10^{7}$, dan $1,56 \times 10^{11}$ pada konsentrasi umpan $0,2 \mathrm{~kg} / \mathrm{L}$, Kadar sari jahe tertinggi diuji secara TSS sebesar $270 \mathrm{mg} / \mathrm{L}$ dan uji centrifuge 6,67\% pada konsentrasi umpan 0,6 kg/L. Semakin tinggi konsentrasi umpan, maka nilai tahanan ampas dan tahanan medium filter pada filter press akan semakin tinggi, sebanding dengan peningkatan nilai konsentrasi produk. Perbedaan kadar sari jahe pada beberapa konsentrasi tidak begitu signifikan, sehingga dapat disimpulkan penggunaan konsentrasi umpan sari jahe paling tepat untuk mendapatkan kinerja filtrasi terbaik dan meningkatkan serta menjaga umur alat filter press yaitu dengan konsentrasi umpan $2 \mathrm{~kg}$ ampas jahe per 10 liter air dan beroperasi pada tekanan $2 \mathrm{~kg} / \mathrm{cm}^{2}$ dan laju alir umpan 5,66 $\times 10^{-11}$ $\mathrm{m} / \mathrm{s}^{2}$.

\section{DAFTAR PUSTAKA}

Geankoplis, C.J., 1983, "Transport Process and Unit Operation", Ally and Bacon,Inc, United State of America

Handayani, D. \& Ikhsan Diyono 2012. Pemanfaatan Ampas Jahe Limbah Industri Jamu Dan Minuman Untuk Produksi Minyak Jahe Dengan Destilasi Kohobasi Vacuum. Metana, 8(1):24-29

Pangestu, A. \& Abriyani, D. 2016. Pengaruh Perbedaan Tekanan Terhadap Nilai Efisiensi Proses Filtrasi $\mathrm{CaCO} 3$ Dengan Menggunakan Plate and Frame Filter Press. Jurnal Laboratorium Operasi Teknik Kimia.

Rachma, Z.N. \& Suparno. 2016. Sistem Filtrasi Dengan Karbon Aktif Kayu Sengon, Kerikil Aktif Sungai Krasak, Dan Pasir Aktif Pantai Indrayanti Pada Air Sumur Di Lppmp Uny Sebagai Air Minum. E-Journal Fisika, 5(2):76-81

Sahruromdon, M. \& Septiriana, I. 2017. Filtrasi Caco3 Menggunakan Filter Plate \& Frame Dengan Variasi Konsentrasi Dan Variasi Jumlah Plate \& Frame. Universitas Sultan Ageng Tirtayasa. Cilegon Banten

Sutherland, K. 2008. Filters and Filtration Handbook. Fifth edition. Elsevier: Hungary 